\title{
Transcript levels of members of the SLC2 and SLC5 families of glucose transport proteins in eel swimbladder tissue: the influence of silvering and the influence of a nematode infection
}

\author{
Gabriel Schneebauer • David Mauracher • \\ Birgit Fiechtner • Bernd Pelster
}

Received: 9 August 2017 / Accepted: 5 December 2017 /Published online: 11 January 2018

(C) The Author(s) 2018. This article is an open access publication

\begin{abstract}
The rate of glucose metabolism has been shown to be correlated to glucose uptake in swimbladder gas gland cells. Therefore, it is assumed that in the European eel silvering, i.e., the preparation of the eel for the spawning migration to the Sargasso Sea, coincides with an enhanced capacity for glucose uptake. To test this hypothesis expression of all known glucose transport proteins has been assessed at the transcript level in yellow and in silver eels, and we also included Anguillicola crassus infected swimbladders. Glucose uptake by rete mirabile endothelial cells could be crucial for the countercurrent exchange capacity of the rete. Therefore, this tissue was also included in our analysis. The results revealed expression of ten different members of the slc2 family of glucose transporters, of four slc 5 family members, and of kiaa1919 in gas gland tissue. Glucose transporters of the slc2 family were expressed at very high level, and $s l c 2 a 1 b$ made up about $80 \%$ of all slc2 family members, irrespective of the developmental state or the infection status of the eel. Overall, the slc 5 family contributed to only about $8 \%$ of all detected glucose transport transcripts in gas gland tissue, and the $s l c 2$ family to more than $85 \%$. In rete capillaries, the contribution of
\end{abstract}

G. Schneebauer · D. Mauracher · B. Fiechtner •

B. Pelster $(\bowtie)$

Institute of Zoology, Leopold-Franzens-Universität Innsbruck,

Technikerstr.25, 6020 Innsbruck, Austria

e-mail: bernd.pelster@uibk.ac.at

G. Schneebauer · D. Mauracher · B. Fiechtner · B. Pelster Center for Molecular Biosciences, University of Innsbruck, Innsbruck, Austria sodium-dependent glucose transporters was significantly higher, leaving only $66 \%$ for the slc 2 family of glucose transporters. Neither silvering nor the infection status had a significant effect on the expression of glucose transporters in swimbladder gas gland tissue, suggesting that glucose metabolism of eel gas gland cells may not be related to transcriptional changes of glucose transport proteins.

Keywords Swimbladder · European eel · Glucose transport $\cdot$ Metabolism $\cdot$ mRNA expression . Transcription · Gas gland · Rete mirabile $\cdot$ Silvering · Anguillicola crassus

\section{Introduction}

Gas secretion in the swimbladder is dependent on glucose metabolism, resulting in the production of lactic acid in the glycolytic pathway, and of $\mathrm{CO}_{2}$, generated in the pentose phosphate shunt (Pelster and Scheid 1993; Walsh and Milligan 1993; Pelster et al. 1994; Pelster 1995b). Along the partial pressure gradient, $\mathrm{CO}_{2}$ diffuses from gas gland cells into the swimbladder, contributing by about $20 \%$ to newly secreted gas (Kobayashi et al. 1990), and into the blood, causing an acidification of the blood during passage of the gas gland cells. Similarly, lactic acid is released into the blood, adding to the acidification (Pelster 1995a). The acidification of the blood during passage of the gas gland tissue switches on the Root effect, so that oxygen is released from the hemoglobin and diffuses into the 
swimbladder along the partial pressure gradient (Pelster and Weber 1991; Pelster and Randall 1998; Pelster 2001). Accordingly, oxygen and $\mathrm{CO}_{2}$ are the main gases secreted into the swimbladder in the European eel (Kobayashi et al. 1990).

Gas secretion into the swimbladder therefore is dependent on glucose uptake from the blood, because internal glycogen stores do not appear to be of any importance (Pelster 1995b). A comparison of transcript levels of glucose transport proteins GLUT1-4 in various tissues of Atlantic cod Gadus morhua revealed that the GLUT1 transport protein is expressed in most tissues examined, and glut 1 expression accounted for $97.6 \%$ of the glucose transporter transcripts in gas gland tissue (Hall et al. 2014). Furthermore, in gas gland tissue glut 1 expression was several fold higher than in other tissues (brain, heart, red blood cells), and the elevated level of glut1 transcript expression in gas gland cells coincided with an elevated rate of glucose consumption, as determined from ${ }^{3} \mathrm{H}_{2} \mathrm{O}$ production from labeled glucose (Hall et al. 2014). In gas gland tissue, a linear correlation between glut 1 transcript expression and glucose metabolism was observed, and lactate production of gas gland cells was 11-fold higher than in cardiac muscle cells, demonstrating the importance of glucose uptake and lactate production in gas gland tissue. A recent detailed study on glucose metabolism in gas gland tissue of the Atlantic cod confirmed the critical importance of the GLUT1 transport protein for the rate of glucose utilization (Clow et al. 2016).

Searching the fugu Takifugu rubripes database for glucose transporter genes, 22 genes for facilitative glucose transporters and seven genes for sodium-dependent glucose cotransporters were detected (Munakata et al. 2012). Using RT-PCR, 7 out of the 22 genes for facilitative glucose transporters were found to be expressed at higher levels, but only glut $1 a$ and glut6 could be detected using in situ hybridization. Expression of sodiumdependent glucose transporter genes was very low and not pursued any further (Munakata et al. 2012).

The basics of swimbladder metabolism of the European eel have been obtained by analyzing yellow eels, i.e., the juvenile stage of the eel living in the European freshwater system. In a process named silvering, the eel prepares for the migration back to the spawning grounds in the Sargasso Sea. During this migration, eels perform daily vertical migrations and therefore are exposed to very high hydrostatic pressures up to $100 \mathrm{~atm}$ (Aarestrup et al. 2009; Righton et al. 2016;
Schabetsberger et al. 2016). During silvering, the retia mirabilia, sophisticated and very effective countercurrent systems, are significantly enlarged, indicating an improvement of the countercurrent concentrating ability. In addition, the performance of the swimbladder is improved by increasing swimbladder wall thickness and guanine deposition (Kleckner 1980a; Kleckner 1980b; Yamada et al. 2001). In the American eel Anguilla rostrata, a five-fold increase in the rate of gas deposition has been recorded in silver eels (Kleckner 1980a). It therefore is assumed that these silvering induced changes are connected to a significant improvement in swimbladder function (Sebert et al. 2009; Righton et al. 2012). The rate of gas secretion has been shown to be correlated to the rate of glucose uptake (Pelster and Scheid 1993) and to the rate of lactate production (Pelster 1995b). Accordingly, an improvement of swimbladder function in silver eels will require an increased uptake of glucose.

Analysis of the transcriptional changes that occur during silvering in gas gland tissue surprisingly did not provide any indication for an enhanced glycolytic activity in silver eels, but for glut 5 and 6 , elevated transcript levels were detected in silver eel gas gland tissue as compared to yellow eel gas gland. For glut1, the most important glucose transporter in Atlantic cod gas gland, however, no difference was detected (Pelster et al. 2016). For European eel, the importance of the various glucose transport proteins has not been assessed, and it therefore appears possible that, in contrast to the Atlantic cod, in the eel swimbladder glucose metabolism is influenced or perhaps even controlled by several glucose transport proteins.

In addition to the gas gland cells, the retia mirabilia, representing a fantastic countercurrent system, are crucial for swimbladder function. Rete capillaries are not only permeable to gas molecules, metabolites like lactate are also concentrated in the rete and this requires transport proteins. Most transport processes at some point require energy, derived from glucose metabolism. Surprisingly, analysis of glucose metabolism of rete capillaries revealed that glucose is almost completely converted to lactate, although rete tissue also is exposed to high oxygen levels (Rasio 1973). In the present study, we therefore searched the genome of the European eel for possible members of the glucose transporter families SLC2 (GLUT-transporters), SLC5 ( $\mathrm{Na}^{+}$-dependent glucose transport proteins, SGLT), and KIAA1919 (NaGLT1) and determined the transcript level of these 
proteins in gas gland tissue. Members of the SLC2 family are facilitative glucose transporters, allowing glucose transport along a concentration gradient (Mueckler and Thorens 2013), while members of the SLC5 family and also KIAA1919 couple glucose transport to the downhill sodium transport (Wright and Turk 2004). In addition to gas gland tissue, we also analyzed the capillary tissues of the rete mirabile for glucose transporter transcript levels to test the hypothesis that rete membranes and gas gland cells use a different set of glucose transport proteins, allowing for an independent control of glucose metabolism in these two tissues. Because following the introduction of the nematode Anguillicola crassus into the European freshwater system the swimbladder of a large fraction of European yellow and silver eels is infected with this nematode (Moravec 1992; Schabuss et al. 2005), we also included gas gland tissue of infected yellow and silver eels in our analysis. Due to the hematophagous and histophagous feeding habits of the nematode, it appears possible that the infection of the swimbladder has an influence on glucose uptake of the gas gland tissue. A comparison of the gas gland transcriptome of uninfected and infected silver eels with uninfected yellow eels suggested that the nematode may be able to modify transcriptional activity of gas gland cells (Pelster et al. 2016).

\section{Materials and methods}

Animals

All experiments were performed with female European eels (Anguilla anguilla). Yellow and silver eels were caught by local fishermen in Lake Constance, Bregenz, Austria, and kept in an outdoor freshwater basin at the Institute of Zoology at the University of Innsbruck, not exceeding 3 weeks. Two days prior to sampling, fish were transferred into an indoor freshwater aquarium. Yellow eels were also caught by local fishermen in the open water of the River Elbe, close to Winsen (Luhe), Germany, and kept in an outdoor basin with a freshwater supply at the Thünen Institute of Fisheries Ecology, Ahrensburg, Germany, until sampling, not exceeding 7 days. Table 1 shows the morphometrics of uninfected and infected yellow and silver eels chosen for the experiments. The silver index was calculated according to Durif et al. (2005), and the ocular index according to Pankhurst (Pankhurst 1982).
Tissue preparation

Eels were anesthetized with neutralized tricaine methanesulfonate (MS-222; $0.1 \mathrm{~g} \mathrm{l}^{-1}$ ) and subsequently decerebrated and spinally pithed. The abdominal wall was opened ventrally, and the swimbladder was carefully exposed. The artery and vein supplying blood to and removing it from the rete mirabile were occlusively cannulated using PE50 catheters. Rete mirabile and swimbladder tissue were perfused with heparinized (No. H3393; Sigma-Aldrich Co. LLC., St. Louis, MO, USA; 100 i.U. $\mathrm{ml}^{-1}$ ) Ringer's solution, which contained (in mmol $1^{-1}$ ) NaCl, 124; KC1, 5; $\mathrm{MgSO}_{4}\left(7 \mathrm{H}_{2} \mathrm{O}\right), 0.9$; $\mathrm{CaCl}_{2}\left(2 \mathrm{H}_{2} \mathrm{O}\right), 1.1 ; \mathrm{NaHCO}_{3}, 10$; Glucose, 5; to clear the tissue from blood cells (Pelster et al. 1989). After removal of blood cells, the two retia mirabilia and the gas gland tissue were carefully dissected, quickly dried on absorbent paper, transferred into $1 \mathrm{ml} \mathrm{RNAlater}{ }^{\mathrm{TM}}$ solution (Invitrogen by Thermo Fisher Scientific Inc., Waltham, MA, USA), and immediately shock frozen in liquid nitrogen. Following perfusion, tissue preparation and cleaning took no more than $2 \mathrm{~min}$. Tissues were then stored at $-80{ }^{\circ} \mathrm{C}$ until further use.

After completing tissue preparation, the number of nematodes isolated from infected swimbladders was counted. Eels with no or one small (length about $4 \mathrm{~mm}$ ) Anguillicola crassus inside the swimbladder without visible modifications of the swimbladder wall were considered as uninfected. In these eels, after peeling off the connective tissue the swimbladder wall was transparent and thin. Heavily infected eels (Pelster et al. 2016) had between 9 and 54 Anguillicola crassus inside the swimbladder. In these fish, the swimbladder contained exudate, was comparatively small and thick walled, and had an opaque appearance. For each group, uninfected yellow, infected yellow, uninfected silver, and infected silver, five animals were analyzed. Rete mirabile tissue was sampled from yellow uninfected $(N=3)$, silver uninfected $(N=5)$, and silver infected eels $(N=5)$. Tissue sampling was performed in compliance with the Austrian law and the guidelines of the Austrian Federal Minister for Education, Arts and Culture.

Isolation of total RNA and preparation of cDNA

Swimbladder and rete mirabile tissue was homogenized in Precellys tubes CKMix (No. KT03961-1-009.2), with a Precellys 24 homogenizer (Bertin Technologies, France) $(2 \times 30 \mathrm{~s}$ at $6000 \mathrm{rpm}, 45 \mathrm{~s}$ break). Total RNA 
Table 1 Morphometrics, silvering index calculated according to Durif et al. (2005) and ocular index calculated according to Pankhurst (1982) of uninfected and infected yellow and silver eels. Overall mean values \pm S.E.M.; $N=5$

\begin{tabular}{llcccc}
\hline & & Yellow uninfected & Silver uninfected & Yellow infected & Silver infected \\
\hline Body mass & $(\mathrm{g})$ & $379,80 \pm 110.54$ & $906.00 \pm 68,30$ & $235.60 \pm 34.40$ & $870.00 \pm 76.61$ \\
Body length & $(\mathrm{cm})$ & $64.20 \pm 5.86$ & $85.50 \pm 2,52$ & $52.80 \pm 2.44$ & $83.40 \pm 2.50$ \\
Pectoral fin length & $(\mathrm{mm})$ & $26.68 \pm 2.67$ & $43.02 \pm 0.89$ & $22.92 \pm 1.57$ & $41.74 \pm 2.33$ \\
Horizontal eye diameter & $(\mathrm{mm})$ & $6.88 \pm 0.52$ & $9.87 \pm 0.32$ & $5.94 \pm 0.43$ & $9.94 \pm 0.28$ \\
Vertical eye diameter & $(\mathrm{mm})$ & $6.08 \pm 0.32$ & $9.32 \pm 0.45$ & $5.80 \pm 0.37$ & $8.96 \pm 0.33$ \\
Silver index & & $2.60 \pm 0.24$ & $4.50 \pm 0.34$ & $2.40 \pm 0.25$ & $4.20 \pm 0.49$ \\
Ocular index & & $5.16 \pm 0.25$ & $8.53 \pm 0.45$ & $5.24 \pm 0.47$ & $8.46 \pm 0.48$ \\
\hline
\end{tabular}

was isolated using the Qiagen miRNeasy® Mini Kit (No. 217004; Qiagen GmbH, Hilden, Germany) according to the manufacturer's instructions. Quality of extracted RNA was assessed by electrophoresis on a $1.5 \%$ agarose-gel, confirming the integrity of $18 \mathrm{~S}$ and $28 \mathrm{~S}$ RNA-bands. RNA concentration was determined using the Quant-iTTM RiboGreen ${ }^{\circledR}$ RNA Assay Kit (No. R11490; Invitrogen by Thermo Fisher Scientific Inc., Waltham, MA, USA) and a VICTOR ${ }^{\mathrm{TM}}$ X4 Multilabel Plate Reader (PerkinElmer, Inc., Waltham, MA, USA). A total of 450 ng RNA was applied for first strand cDNA synthesis. The RNA was preincubated with $2.5 \mu$ l Random Hexamer Primer (No. SO142, Thermo Fisher Scientific Inc., Waltham, MA, USA) at $70^{\circ} \mathrm{C}$ for 5 min before the RT reaction was set up using RiboLock $^{\mathrm{TM}}$ RNase Inhibitor, $10 \mathrm{mM}$ dNTP Mix, and RevertAid H Minus Reverse Transcriptase in $50 \mu \mathrm{l}$ approaches (No. EO0381, No. R0191, and No. EP0451, respectively, Thermo Fisher Scientific Inc., Waltham, MA, USA). For each tissue sample, a cDNA synthesis without reverse transcriptase (noRT) was performed to detect DNA contaminations in the final qPCR reaction.

Primer design and preparation of standard curves

Possible members of the glucose transporter families SLC2 (GLUT-transporters) and SLC5 (SGLTtransporters) and the glucose transporter KIAA1919 (NaGLT1) (Horiba et al. 2003) were identified by searching the draft genome sequence of European eel, Anguilla anguilla, (Henkel et al. 2012). Predicted cDNAs are available at http://www.zfgenomics. com/sub/eel.

This search identified 12 possible members of the slc2 family of glucose transporters, five possible members of the slc5 family of glucose transporters, and the sodium-dependent glucose transporter kiaa1919. The sequences g8232 and g18545 each represent discrete gene species of glucose transporter slc2al (later referred to as slc2ala and slc2a1b), and the sequences g13360 and g15843 each represent discrete gene species of the glucose transporter slc2all (later referred to as slc2a11a and slc2a11b). For all identified possible glucose transporters, primers were designed using Primer Express@ Software for RealTime PCR3.0.0 (Applied Biosystems, Foster City, CA, USA). Primers were purchased from Microsynth (Balgach, Switzerland). All primer pairs, the gene numbers of the corresponding predicted cDNAs, and the aliases are listed in Table 2. For three transporters (slc2a1a; slc2a9; slc5a2), the initially designed primer pairs did not result in reliable amplification of a defined fragment. Therefore a second set of primers was designed (Table 2). Again, no defined fragment could be amplified. We therefore assumed that these transporters are only expressed with a very low copy number so that a reliable quantification is not possible.

A primer matrix with four different concentration pairs of the forward and reverse primer $\left(3 \times 10^{-6}\right.$ and $9 \times 10^{-6} \mathrm{~mol} \mathrm{l}^{-1}$ for each primer) was used to identify the optimal primer concentration for the amplification reaction. The resulting PCR products of the primer matrix were purified using the QIAquick® PCR Purification Kit (No. 28106; Qiagen GmbH, Hilden, Germany); DNA concentration was determined using the Quant-iTTM PicoGreen ${ }^{\circledR}$ dsDNA Assay Kit (Invitrogen by Thermo Fisher Scientific Inc., Waltham, MA, USA) and used to create 7-point dilution series from $10^{-9}$ to $10^{-3} \mathrm{~mol} \mathrm{l}^{-1}$ to calculate a standard curve for each glucose transporter. 
Table 2 Aliases, gene numbers and sequences of forward and revers primers of all glucose transporters analyzed in this study

\begin{tabular}{|c|c|c|c|c|}
\hline $\begin{array}{l}\text { Glucose } \\
\text { transporter }\end{array}$ & Aliases & $\begin{array}{l}\text { Corresponding } \\
\text { cDNA }\end{array}$ & Primer forward & Primer reverse \\
\hline kiaa1919 & naglt1, naglut & g11656 & TGCAGTCGCTGGCTAATCAC & CATCCCCAGTCCGAGAAAAG \\
\hline slc2ala & glut1, gtr1 & g8232 & GGCACTGAGGACGTGAGTGA & TCCATCGCCATCTTCAGACTCT \\
\hline slc $2 a 1 b$ & glut1, gtr1 & g18545 & GCATCAACGCCGTCTTCTACT & CTGGGCCACTCCTGCTTTC \\
\hline slc2a2 & glut 2, gtr2 & $\mathrm{g} 6508$ & TTCGGTGGTGCTGGTTGA & CCCCCATATCCAATCAGAGTCA \\
\hline slc2a3 & glut3, gtr3 & g12848 & $\begin{array}{l}\text { CAAGGAGGAAGAGG } \\
\text { CACAGAA }\end{array}$ & CGCTCACATCCTCAGAACCA \\
\hline slc2a4 & glut 4, gtr 4 & g3699 & CATGTGTTTGTGTGCCATCATC & ACGGCACGCTTTCCAAGAG \\
\hline $\operatorname{slc} 2 a 5$ & glut 5, gtr 5 & g21637 & CCCGGAAACCAAAAACAAGA & CCCATTTCTCTCCGCAAACA \\
\hline slc2a6 & glut6, gtr6 & g25279 & CATGCCCTGCCCTCAATG & GGGTCAAAGGGTGTGGTCTGT \\
\hline slc2a8 & glut 8, gtr 8 & g7936 & ACCCCCGGTTGCAGTTG & GTCACCACAGACCCAAACCAT \\
\hline slc2a9 & glut 9, gtr 9 & g21280 & GGGTTGCGTGATCGGAATC & AGGGAACTCCAGCTGGTCCTA \\
\hline slc2alo & glut10, gtr10 & g6928 & CCCGCTGGTCTGAGAGGAA & ATTAGCTGCCCAGTTGAAGCA \\
\hline slc2alla & glut11, gtr11 & g13360 & $\begin{array}{l}\text { CAGAGGAACTGCTCACCTTG } \\
\text { CT }\end{array}$ & GCCCGCCAATGGTGAAG \\
\hline slc $2 a 11 b$ & glut11, gtr11 & g15843 & CTGTGCTGGCAGTGTTTAGCA & CCGGGCCAGAATGATCATC \\
\hline slc5al & sglt1 & $\mathrm{g} 18418$ & AAGCTGCTGCCCATGTTCAT & $\begin{array}{l}\text { TCTGTGTACAGGATGCGACT } \\
\text { GAT }\end{array}$ \\
\hline $\operatorname{slc} 5 a 2$ & sglt2 & g14486 & TGGTTCTGCGGCCTGAGT & CGACCTCCTGCTCCGTAAGT \\
\hline slc5a9 & sglt4 & g9021 & CCACCAATCACCGCTGTCT & CTGCTCATTGACACGTTTCCA \\
\hline slc5a10 & sglt5 & g2925 & CACCCGTCACTGCCATCTT & GAATGCTCCCGCCTCGTT \\
\hline slc5all & sglt6, smit $2, k s t 1$ & g8799 & GGATACCGCGTGCTTGCT & GGTTGCCGTTGACGAAGTG \\
\hline slc2ala & glut 1, gtrl & g8232 & GGGAGGCGTAAATCCATGCT & CAAAGCTGAGAAGCCCATCAG \\
\hline $\operatorname{slc} 2 a 9$ & glut 9, gtr 9 & g21280 & GCTGGGTGGTCGTAATGTTGT & TGCATACGGCAGGAGACCTT \\
\hline slc5a2 & sglt2 & g14486 & TTCTCTGCATCGTGTCCATCA & GCTCTGGGCAGCCTGAAC \\
\hline
\end{tabular}

qPCR assays

Quantitative real-time PCR was performed using the Power SYBR ${ }^{\circledR}$ Green PCR Master Mix (Applied Biosystems $^{\mathrm{TM}}$ by Thermo Fisher Scientific, Inc., Waltham, MA, USA). Each reaction contained $1 \mu \mathrm{l}$ ultrapure water, $1 \mu \mathrm{BSA}, 1 \mu \mathrm{l}$ cDNA (representing 9 ng of input RNA), $1 \mu$ forward and $1 \mu$ reverse primer, and $5 \mu \mathrm{l}$ SYBR $®$ Green and was assessed on a QuantStudio 3 Real-Time PCR System (Thermo Fisher Scientific Inc., Waltham, MA, USA), with the following cycling conditions: $2 \mathrm{~min}$ at $50^{\circ} \mathrm{C}, 10 \mathrm{~min}$ at $95^{\circ} \mathrm{C}, 40$ cycles of $15 \mathrm{~s}$ at $95^{\circ} \mathrm{C}$, and $1 \mathrm{~min}$ at $60^{\circ} \mathrm{C}$, and a final melting curve from 60 to $95{ }^{\circ} \mathrm{C}$ to identify possible primer dimers and verify reaction specificity. Each sample was measured in triplicates. Each tissue was analyzed on a single plate with additional noRT and no template controls to test for DNA contaminations. On all plates, glucose transporter slc2alb was measured in $1 \mu \mathrm{l}$ of a defined cDNA pool and used as a calibrator. $C_{\mathrm{T}}$ levels for all other glucose transporters were calculated relative to this calibrator, so that a quantitative comparison between different plates was possible. Following this normalization, the $C_{\mathrm{T}}$-values were used for determination of the absolute copy number of the glucose transporter transcripts based on the respective standard curves. Copy numbers were calculated per 10 ng total RNA. Occasionally, due to varying primer efficiencies, copy numbers had to be corrected using a correction factor calculated according to Pérez et al. (2013).

Statistics

Data are presented as mean \pm S.E.M. with $N$ giving the number of animals analyzed. Outliers were detected using IBM SPSS Statistics Version 24.0 (IBM Corp., Armonk, NY, USA). Shapiro-Wilk tests were performed using SigmaPlot 13.0 (Systat Software, Inc., San Jose, CA, USA), to test data of experimental groups for normal distribution. ANOVA on Ranks with subsequent 
Holm-Sidak or Dunn's post hoc multiple comparison tests were performed to test for statistically significant differences between the experimental groups. Significance of differences was accepted when $P<0.05$.

\section{Results}

Using the primer sets designed on the basis of the eel genome, we obtained the expected amplicons for all glucose transport family members except slc2ala, slc2a9, and slc5a2.

In uninfected yellow eel gas gland tissue, the member of the slc2 family of glucose transporters with the highest transcript level was $s l c 2 a 1 b$, expressed with $1.16 \pm 0.48 \times 10^{6}$ copies per $10 \mathrm{ng}$ of total RNA (Fig. 1a). In uninfected silver eel gas gland, this transporter was expressed at a similar high level with $0.85 \pm$ $0.27 \times 10^{6}$ copies per $10 \mathrm{ng}$ of total RNA. The second highest expression level was found for slc2al0 with $90,486 \pm 20,803$ copies per $10 \mathrm{ng}$ of total RNA and $38,228 \pm 5885$ copies per $10 \mathrm{ng}$ of total RNA in uninfected yellow and silver eel gas gland, respectively. The only difference between uninfected yellow and silver eel gas gland tissue in the expression of members of the slc2 family was detected for $s l c 2 a 2$. In yellow eels, $5020 \pm$ 766 copies per $10 \mathrm{ng}$ of total RNA were found for slc2a2, while in silver eel only $837 \pm 94$ copies per 10 ng of total RNA were detected $(P<0.05)$.

Of the $s l c 5$ family of glucose transporters, slc $5 a 11$ was expressed with $25,990 \pm 5631$ copies per $10 \mathrm{ng}$ of total RNA in yellow eels, and in silver eel tissue a similar value was detected with 17,318 \pm 407 copies per $10 \mathrm{ng}$ of total RNA (Fig. 1b). Only slc5al was expressed at a lower level in silver eels with only $2712 \pm 406$ copies per $10 \mathrm{ng}$ of total RNA (Fig. 1b).

The sodium-dependent glucose transporter kiaa1919 was also detected with $44,589 \pm 12,556$ copies per $10 \mathrm{ng}$ of total RNA in uninfected yellow eel gas gland, and there was no difference in expression compared to uninfected silver eels (Fig. 1b).

Looking at the influence of the nematode infection on the distribution of the glucose transporters in gas gland tissue for the transporter expressed at the highest level $(s l c 2 a 1 b)$, no difference could be detected between uninfected and infected yellow or silver eel gas gland. In infected yellow eels, expression of slc2a6 was significantly higher than in silver eels, but this glucose transporter was also expressed at a lower level, i.e., at a level of about 1000 copies per $10 \mathrm{ng}$ of total RNA (Fig. 1a).

Plotting the fractional contribution of the different glucose transport transcripts (Fig. 2) revealed that within the slc 2 family, slc $2 a 1 b$ with about $80 \%$ by far exceeded the expression level of all other family members, and there was no significant difference between yellow and silver eels and uninfected and infected eels (Fig. 2a). The second important transporter was slc2al0 which contributed between 6.9 and $9.0 \%$ to total expression, and in infected silver eels even a value of $14.1 \%$ was found. The contribution of $\operatorname{slc} 2 a 2,5,6$, and 8 was even below $1 \%$ in gas glands of all experimental groups. No significant difference in the fractional contribution of the various glucose transporters was found between yellow and silver eels and uninfected and infected eels.

The fractional contribution of the different slc 5 family members was much more uniform (Fig. 2b), and in uninfected yellow eel gas gland tissue, each of slc $5 a 9$, slc5a10, and slc5a11 contributed close to about $30 \%$ to the total transcript number, leaving $11.4 \pm 1.6 \%$ for slc5a1. There was no significant difference in the expression level of slc 5 family members between yellow and silver eels and uninfected and infected eels.

Testing the expression of glucose transporters in the rete mirabile of the swimbladder revealed that the same transcripts already detected in gas tissue were also expressed in rete tissue. Analyzed were three uninfected yellow eels, five uninfected silver eels, and five infected silver eels. No significant differences could be detected for any of the transcripts between these three groups. Therefore, all samples were combined $(N=13)$. Figure 3 presents the expression level of all glucose transporters detected in the rete in comparison to the overall mean values calculated for gas gland tissue. In the rete, $s l c 2 a 1 b$ was also the $s l c 2$ family member expressed at the highest level, but this value, with $191,300 \pm 25,640$ copies per $10 \mathrm{ng}$ of total RNA, was significantly lower than the expression in gas gland tissue (Fig. 3a). In addition to slc2al0 which was expressed at the second highest level, slc2a3 was expressed at almost the same level with $58,429 \pm$ 12,784 copies per $10 \mathrm{ng}$ of total RNA. slc2a5, 6 , and 8 , which were very low in gas gland tissue, also were expressed at the lowest level in the rete mirabile.

Of the slc 5 family, slc $5 a 1$ was expressed at the lowest level with only $5646 \pm 989$ copies per $10 \mathrm{ng}$ of total RNA, significantly lower than the other three members 
Fig. 1 Number of mRNA copies of various members of the $\operatorname{slc} 2$ (a) and the $\operatorname{slc} 5$ (b) family of glucose transporters, and of kiaa1919 (b) per $10 \mathrm{ng}$ total RNA in gas gland tissue of uninfected and infected yellow and silver eels. Due to the large differences in the copy number, data are presented on a $\log$ scale. $N=5$ for each group. Bracket indicates significant differences between groups, $P<0.05$
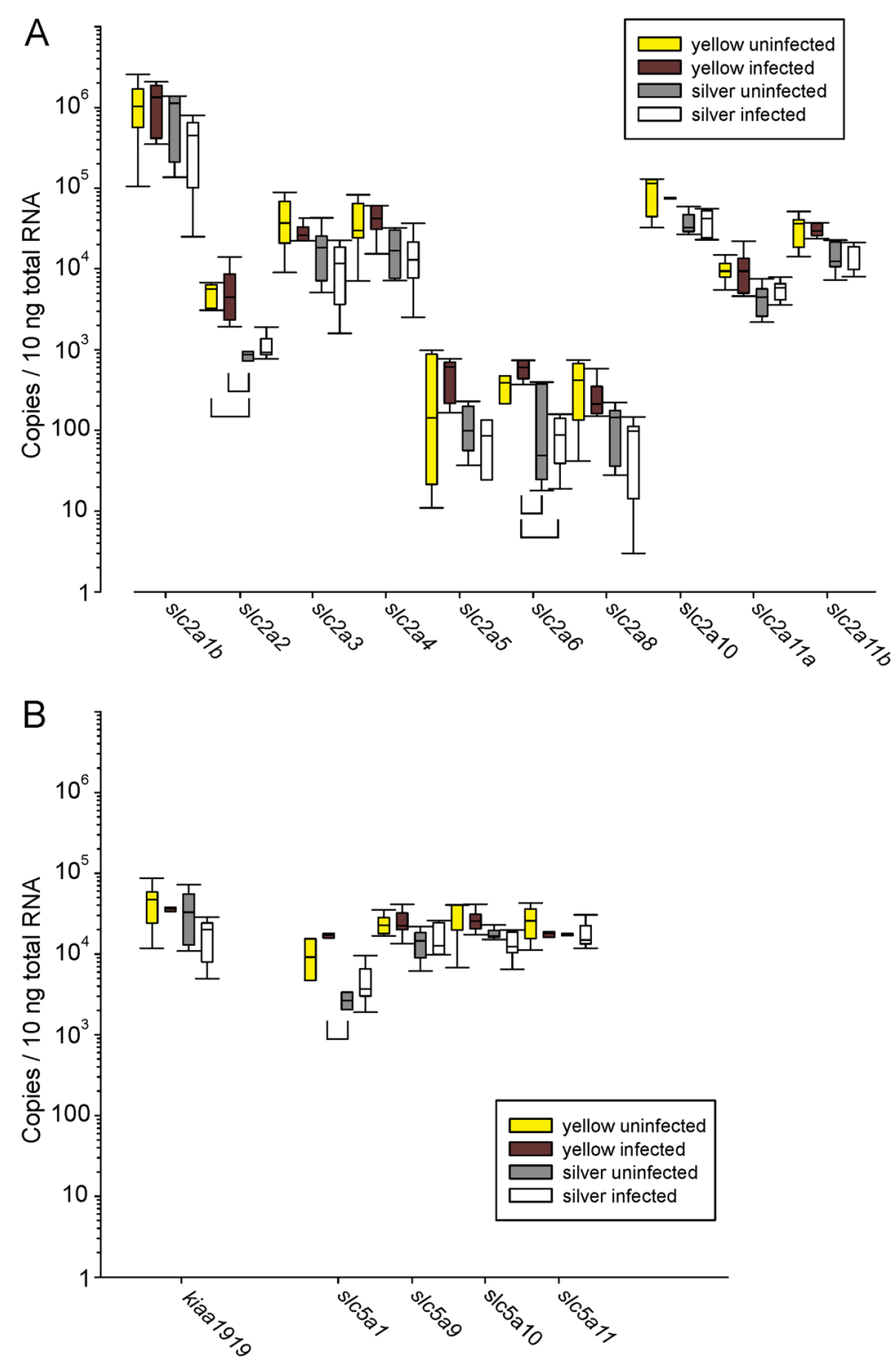

of this family. slc 5 a 10 was expressed at the highest level with $113,536 \pm 18,222$ copies per $10 \mathrm{ng}$ of total RNA. For slc5a9 and slc5a11, 25,136 \pm 3654 and 28,208 \pm 4286 copies were detected, respectively (Fig. $3 b$ ).

Kiaa1919 was expressed at a level of 27,093 \pm 5424 copies per 10 ng of total RNA (Fig. 3b), and this level was not different from expression values obtained for gas gland tissue.

The fractional contribution of the different glucose transport transcripts in the rete revealed significant differences to the picture obtained from gas gland tissue. Of the $s l c 2$ family, slc2alb was again the most important member, but it contributed to about $52 \pm 4 \%$ to the total expression of this family, and slc $2 a 10$ and slc $2 a 3$ added another 22 and 15\%, respectively (Fig. 4a), so that these three transcripts made up $89 \%$ of all transcripts of the slc2 family. Of the slc5 family, slc5a 10 was by far the most important member, making up about $62 \pm 4 \%$ of the total expression (Fig. $4 \mathrm{~b}$ ).

Differences in the glucose transporter expression between gas gland tissue and rete mirabile were also obvious when comparing the total contribution of the two transporter families to all analyzed glucose transporter transcripts (Fig. 5). While in gas gland tissue the slc2 family made up between 81 and $90 \%$ of the total glucose transporter transcripts, in the rete, they 
Fig. 2 Fractional contribution (in $\%$ ) of the different glucose transport transcripts of the $s l c 2$ family (a) and of the slc5 family (b) of glucose transporters in gas gland tissue of uninfected and infected yellow and silver eels. In Fig. 2a, slc2 members contributing less than $1 \%$ to total SLC2 transcripts have been omitted for clarity. Mean \pm S.E.M.; $N=5$ for each group
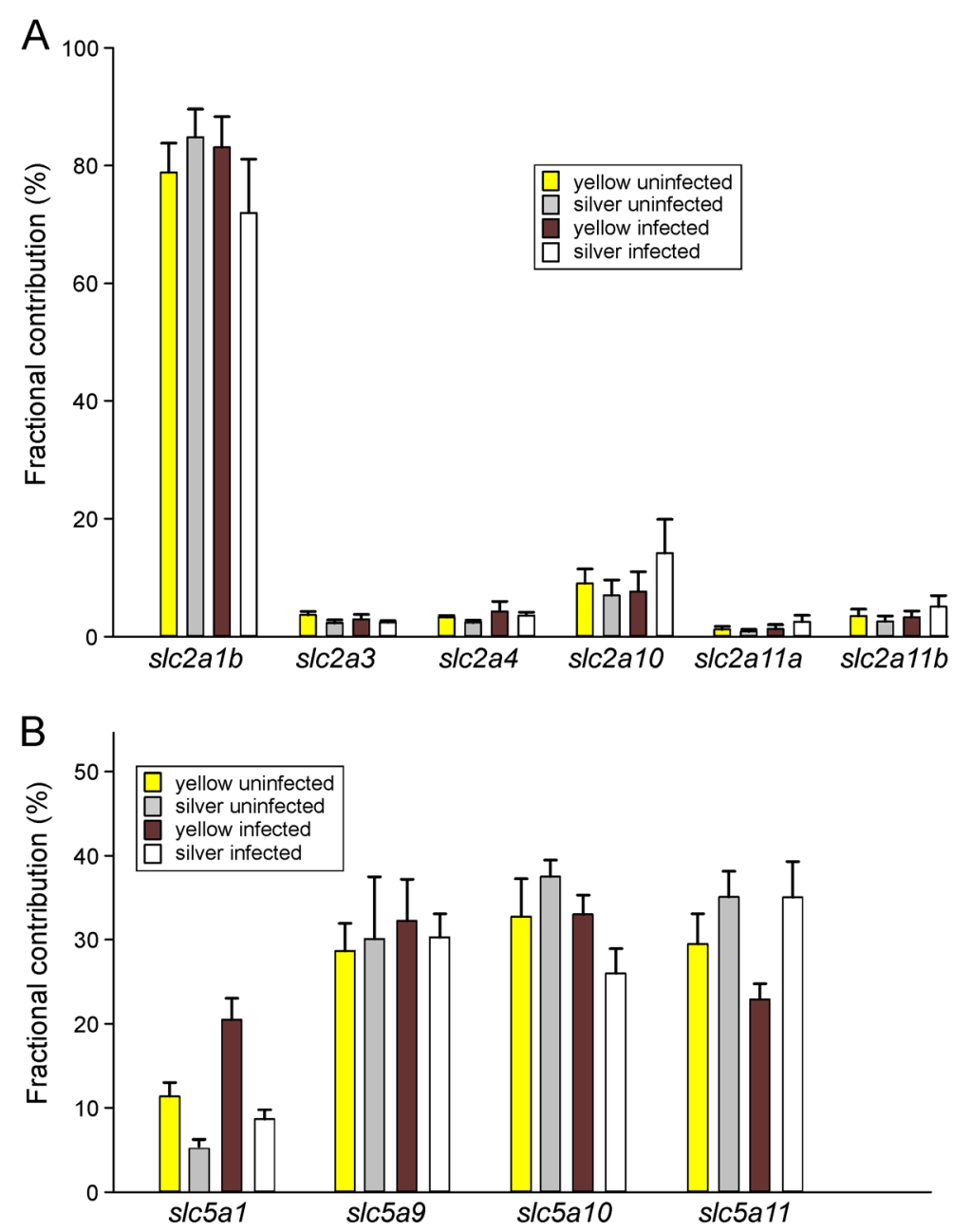

contributed only $66 \pm 2.5 \%$. The contribution of the slc 5 family in turn was significantly elevated compared to gas gland tissue. The contribution of glucose transporter kiaa1919 varied between 2 and 5\% in gas gland tissue and in the rete, and there was no difference between the different tissues and samples.

\section{Discussion}

In fish, a tissue specific distribution of members of the SLC2 family of glucose transport proteins has been reported, and most studies focus on the first four members of this family, i.e., slc2al-4 (alias: glut1-4) (Hall et al. 2014). In fish, a genome duplication resulted in the presence of gene paralogs (Taylor et al. 2001; Meyer and Van de Peer, 2017), which may have been retained as in the case of HIF- $\alpha$ proteins in cyprinids (Rytkönen et al. 2013), but also may have been lost in evolution. Accordingly, we found duplicates of some of the glucose transporters, but not of all. Our genome search identified a number of additional fragments of some glucose transport proteins, but because they were incomplete and could not result in the production of a functioning transport protein, they were omitted. Slc2alb (glut1) appears to be expressed ubiquitously (Hall et al. 2004; Hall et al. 2014). In eel gas gland tissue, slc2alb (glut1) is by far the most dominant member of the slc2 family, and this has also been reported for the Atlantic cod (Hall et al. 2004; Hall et al. 2014). Relative to total RNA, the number of slc2alb (glut1) transcripts was 6-fold higher in eel gas gland tissue than in the rete mirabile. In fugu gas gland tissue, high expression of glutla was detected by RTPCR and in situ hybridization (Munakata et al. 2012). In Atlantic cod, expression of this transporter was also exceptionally high in gas gland tissue compared to other 
Fig. 3 Number of mRNA copies of various members of the $s l c 2$ (a) and the $\operatorname{slc} 5$ (b) family of glucose transporters, and of kiaa1919 (b) per $10 \mathrm{ng}$ total RNA in rete mirabile tissue of European eels. For comparison, the respective expression of the transporters in gas gland tissue (overall mean of all samples) has been included. Due to the large differences in the copy number, data are presented on a $\log$ scale. $N=13$ for the rete mirabile; $N=20$ for gas gland samples. Bracket indicates significant differences between groups, $P<0.05$
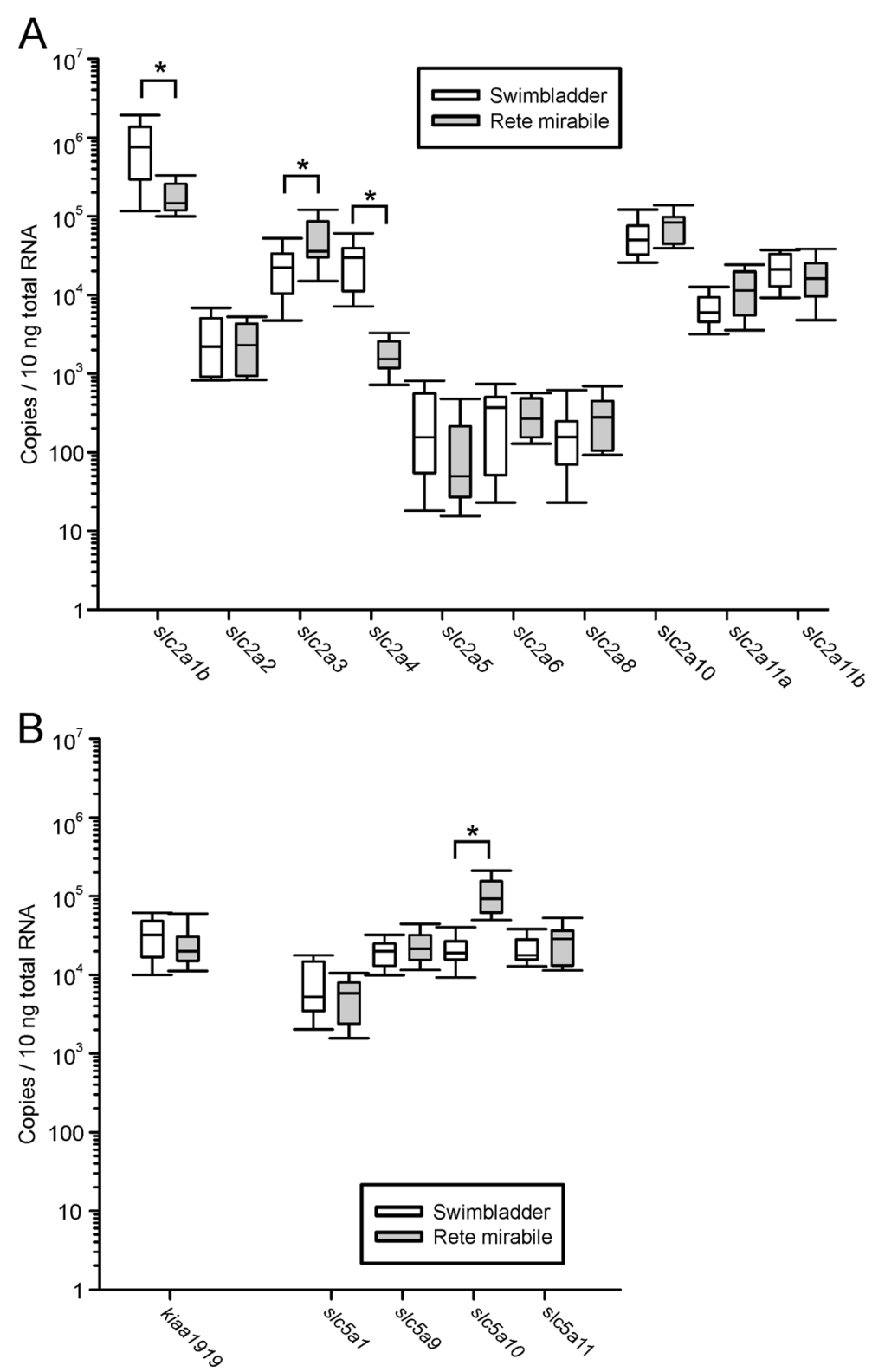

tissues (Hall et al. 2014), and the number of glut1 transcripts coincided with the rate of glucose consumption (Clow et al. 2016), supporting the notion that gas gland tissue has an exceptionally high rate of glucose turn over. In the gas gland, glucose is required for lactate production in the glycolytic pathway and $\mathrm{CO}_{2}$ production in the pentose phosphate pathway. Both metabolites are required for acidification of the blood in order to switch on the Root effect, which in turn is essential for filling the swimbladder with oxygen (Pelster and Weber 1991; Pelster and Randall 1998; Pelster 2001).
SLC2a2 (GLUT2) has been found in liver of rainbow trout Oncorhynchus mykiss (Panserat et al. 2001), and in liver, but also in kidney and intestine of Atlantic cod Gadus morhua (Hall et al. 2006; Hall et al. 2014). In sea bass Dicentrarchus labrax, it has also been detected in larger amounts in brain tissue (Terova et al. 2009), but in eel swimbladder tissue, the $s l c 2 a 2$ transcript contributed less than $1 \%$ to total $s l c 2$ transcripts, suggesting that it does not play an important role in this tissue.

Similarly, slc2a3 (glut3) and slc2a4 (glut4) transcripts are expressed at a low level in gas gland cells. 
Fig. 4 Fractional contribution (in $\%$ ) of the different glucose transport transcripts of the $s l c 2$ family (a) and of the slc5 family (b) of glucose transporters in the rete mirabile of European eels. Mean \pm S.E.M.; $N=13$
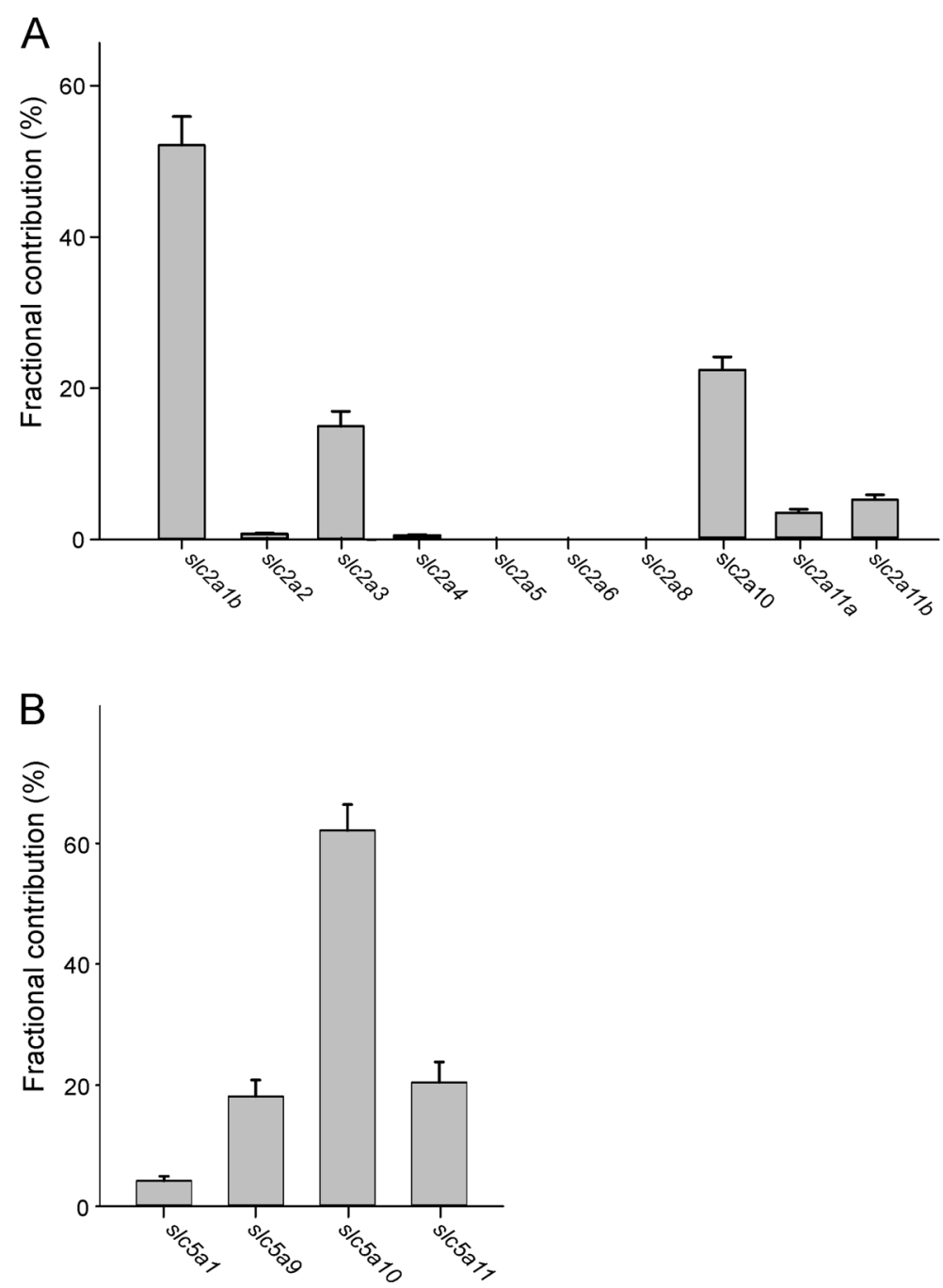

Fig. 5 Comparison of the total expression level of members of the $s l c 2$ family, the slc5 family, and kiaa1919 in gas gland tissue of uninfected and infected yellow and silver eel gas gland tissue and in the rete mirabile. Mean \pm

S.E.M.; gas gland tissue, $N=5$ for each group; rete mirabile, $N=13$. *indicates significant differences between gas gland tissue and rete mirabile, $P<0.05$

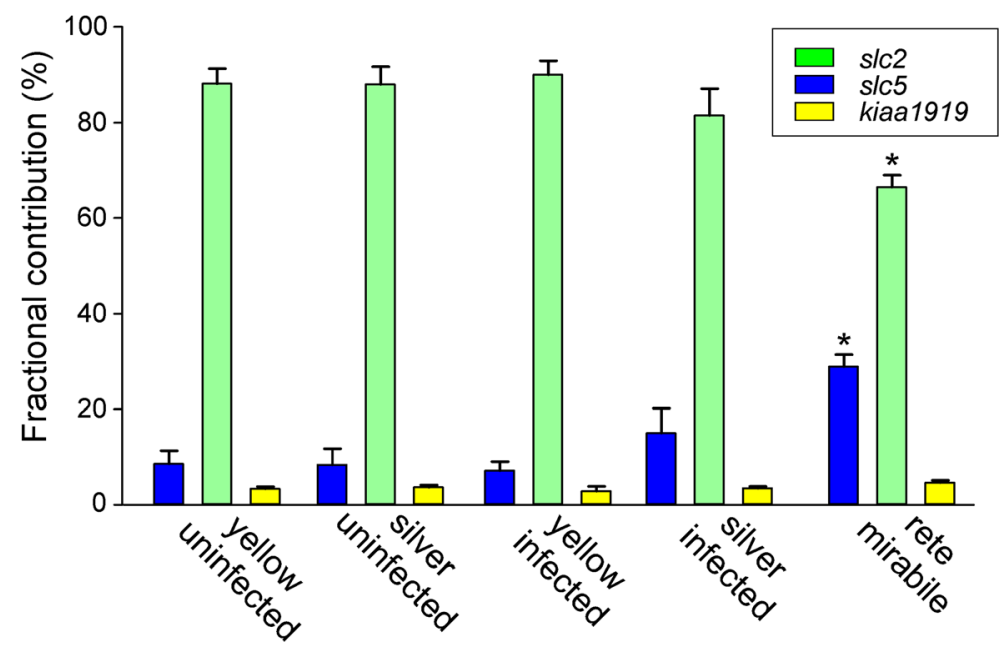


The SLC2a4 (GLUT4) transport protein is considered to be insulin regulated in fish (Capilla et al. 2002; Capilla et al. 2004; Diaz et al. 2009; Polakof et al. 2012; MarinJuez et al. 2014). Our data therefore suggest that insulin is not involved in glucose uptake in gas gland tissue.

While many studies on SLC2 proteins in fish so far focused on SLC2a1-4, in swimbladder gas gland tissue slc2a10 (glut10) contributed between 6.9 and $9.0 \%$ to total transcript level of $s l c 2$ family members, and this was the second highest expression level of all analyzed members of this family. In fugu, glut $11 c 2$ has been detected by RT-PCR, but not by in situ hybridization (Munakata et al. 2012). The functional significance of this transporter, however, remains unclear so far. Slc2a10 and 11 have been found in the human genome, but even in mammals, the role of these transport proteins remains unclear (Mueckler and Thorens 2013).

Sodium-dependent glucose transporters (slc5, alias $s g l t$ ) are most important in gut and kidney (Wright and Turk 2004), but a very low expression level was also reported for gas gland tissue of fugu (Munakata et al. 2012), and compared to the slc2 transporters in the European eel, they contributed only about $10 \%$ to the total transcripts of glucose transporters. Three members of the slc5 family (slc5a9, 10, and 11) appeared to be equally important, contributing about $30 \%$ each to total slc5 transcripts, leaving about $10 \%$ for slc5al. slc5al ( $s g l t 1)$ has been identified in rainbow trout kidney (Sugiura et al. 2003; Conde-Sieira et al. 2013), hindbrain and hypothalamus (Otero-Rodino et al. 2015), and intestine (Polakof et al. 2010; Polakof and Soengas 2013). The swimbladder originates as an outgrowth of the esophagus and therefore is a derivative of the gut, so presence of sodium-dependent glucose transporters appears plausible.

Unfortunately, very little is known about the other three members of the slc5 family (slc5a9-11), which are transcribed at a higher level in gas gland tissue. SLC5a9 (SGLT4) has been isolated from human small intestine, and it is also present in the kidney. In expression studies, it was characterized as a low affinity transporter, transporting sodium and various hexoses like mannose, glucose, and fructose (Tazawa et al. 2005). SLC5a10 (SGLT5) has been identified in human kidney and has also been shown to transport various hexoses in a sodium-dependent manner (Grempler et al. 2012; Fukuzawa et al. 2013). SLC5a11 (alias: SGLT6, SMIT2, KST1) has been shown to transport not only sodium and glucose but also sodium and myo-inositol.
The mammalian SMIT2 protein has been reported to be sensitive to phlorizin, typical for SLC5 glucose transport proteins, and to transport myo-inositol even more effectively than glucose when expressed in Xenopus oocytes or in purified membrane preparations (Coady et al. 2002; Aouameur et al. 2007). The transport characteristics of the eel SLC5 proteins have not been analyzed as yet.

In addition to these well-known families of glucose transporters, the sodium-dependent glucose transporter kiaa1919 (alias NaGlt1) was detected in gas gland tissue. KIAA1919 has been detected and characterized in rat kidney (Horiba et al. 2003; Nawata et al. 2015). Although glucose transport of this transporter is sodium dependent and sensitive to phlorizin, the low sequence identity with members of the SLC2 and the SLC5 family $(<22 \%)$ led the authors to conclude that this is a separate family of glucose transport proteins (Horiba et al. 2003). Compared to the slc2 and the slc5 family of glucose transporters, it was expressed at a low level, and there was no difference in the expression of kiaal919 between yellow and silver eel gas gland. Even in mammals very little is known about this transporter, and this appears to be the first report on this transporter in fish. The physiological significance of this transporter remains to be addressed.

By including silver eel tissue and also tissues from eels with swimbladders infected with the nematode Anguillicola crassus, we were also able to address the influence of silvering and of the nematode on the transcription pattern of slc 2 and $s l c 5$ glucose transporters. In a previous transcriptomic study using unperfused swimbladder tissue, significant differences were detected for some slc2 transporters (slc2a3, 5, and 6; (Pelster et al. 2016)). We confirmed significant differences in the transcript level of slc2a2 and slc2a6, but our comparative analysis revealed that these $s l c 2$ members are expressed at a very low level, i.e., they contributed less than $1 \%$ to total $s l c 2$ transcription (i.e., slc2a2, 5, 6, and 8 ). The physiological significance of these differences therefore remains questionable. In contrast to the European eel, in fugu a high level of glut6 transcripts was detected by RT-PCR and by in situ hybridization (Munakata et al. 2012), suggesting that species specific differences in glucose transport mechanisms may exist. The most important $s l c 2 a 1 b$ transcript made up about $80 \%$ of all slc 2 transcripts in yellow and silver eel gas gland, irrespective of the infection status. Similar results were obtained for the second most important transcript, 
slc $2 a 10$, contributing about $7-9 \%$ to the $s l c 2$ transcripts in all four groups. We therefore conclude from our data, that neither the silvering nor the infection of the swimbladder with the nematode Anguillicola crassus caused a significant modification of the transcription of slc2 family members. In Atlantic cod, glucose turnover has been shown to be related to the mRNA expression of slc2al (Clow et al. 2016). Our data suggest, however, that in the European eel, the adjustment of gas gland tissue glucose metabolism to the spawning migration and the severe changes in hydrostatic pressure associated with the daily vertical migrations in the open ocean (Aarestrup et al. 2009; Righton et al. 2016; Schabetsberger et al. 2016) do not require transcriptional modification of glucose transporters. This could imply that in European eel, the rate of glucose metabolism of gas gland cells is not correlated to the mRNA expression level of glucose transport proteins. Translational activity may play a more important role, or the activity of glucose transport proteins may be regulated. Vagal control of gas gland metabolism has repeatedly been confirmed, and vagotomy abolishes gas secretion (Pelster 1995b; Nilsson 2009; Smith and Croll 2011).

With respect to sodium-dependent transporters in gas gland tissue, high levels of slc5al have been found in infected yellow eel, significantly higher than in uninfected silver eels. It is possible that the thickening of the gas gland tissue in infected swimbladders (Nimeth et al. 2000; Würtz and Taraschewski 2000) caused a modification of glucose transport, and an elevated transcription of glycolytic enzymes has indeed been observed in infected yellow eel gas gland tissue (Pelster et al. 2016). In addition, the infection significantly influenced the transcriptional changes observed during silvering (Pelster et al. 2016), possibly explaining the differences observed between infected silver and infected yellow eels.

An analysis of glucose metabolism of rete capillaries in vitro surprisingly revealed, that although the tissue faces high oxygen partial pressures, anaerobic metabolism dominates. Similar to gas gland cells, lactate is the main end product of glucose metabolism, accounting for more than $95 \%$ of the glucose uptake in rete tissue (Rasio 1973). Comparing slc2, slc5, and kiaa1919 transcript levels of gas gland tissue with the levels measured in the rete mirabile; however, significant differences were detected. Of the members of the slc2 family, slc $2 a 1 b$ contributed close to $50 \%$ to the overall transcript level, which was much less than its contribution in gas gland tissue. Together with slc2a3 and slc2a10, these three transcripts made up close to $90 \%$ of the total slc2 transcripts. Accordingly, while in gas gland tissue, slc2alb was almost exclusively responsible for glucose transport, in rete tissue, these three transporters significantly participate in glucose uptake. As already observed in gas gland tissue, slc2a2, 5, 6, and 8 were almost negligible in their transcript level.

In rete tissue, the transcriptional contribution of the various $s l c 2$ members was more equally distributed than in swimbladder tissue, and the sodium-dependent glucose transporters were much more important. While in uninfected yellow and silver eel gas gland tissue, the sodium-dependent transporters contributed less than $10 \%$ to total glucose transporters, in the rete mirabile, their contribution increased to $28 \%$, suggesting that in the rete, sodium-dependent glucose transport was much more important than in gas gland tissue. As in gas gland tissue, slc5a1 was expressed at a low level. In contrast to the results obtained from gas gland tissue with respect to slc5a9-11, in the rete, slc5a10 was by far the dominating sodium-dependent glucose transporter, contributing 62 $\pm 4 \%$ to the total slc 5 transcripts measured. In mammals, SLC5a10 (SGLT5) expression has only been shown in the kidney, and it appears to transport various monosaccharides (Grempler et al. 2012; Fukuzawa et al. 2013). In swimbladder tissue, only glucose transport appears to be relevant, so far no other hexose has been implicated in swimbladder metabolism. Our data suggest that in the rete, glucose transport is much more dependent on sodium co-transport than in gas gland tissue. Considering the high rate of glucose consumption in gas gland cells, it could be possible that a large fraction of the glucose is in fact taken up by these cells, leaving only low blood glucose concentrations in venous blood returning to the rete mirabile. Thus, sodium-dependent glucose uptake could be required to assure proper supply of nutrients to rete mirabile endothelial cells.

In all gas gland samples, irrespective of the infection status, and in the rete mirabile, kiaa1919 transcripts contributed less than $5 \%$ to total glucose transporter transcripts, and there was no difference between the different samples. Accordingly, the contribution of this transporter to glucose uptake did not appear to be of great importance, and the physiological meaning of this transporter remains to be analyzed.

In conclusion, the results of our study show that in swimbladder gas gland cells of the European eel, slc2alb (glut1) was by far the most dominant member 
of all expressed glucose transporters. However, expression of the members of glucose transporter families slc2 and slc5 was hardly affected by silvering, which has been shown to enhance swimbladder function and thus must be connected to an elevated metabolic activity and acid production. In addition, the infection of the swimbladder with the nematode Anguillicola crassus had no severe effect. This was surprising because an infection of the swimbladder with the nematode significantly impairs acid and gas secretion (Würtz et al. 1996) and thus metabolism of gas gland cells. Taken together these data suggest that, in contrast to cod (Hall et al. 2014), in European eel, glucose metabolism in gas gland cells is not strictly correlated to the mRNA expression level of glucose transport proteins. Obvious differences were established in the expression of glucose transport family members between the rete mirabile and the gas gland. Rete tissue is much more dependent on sodium-dependent glucose uptake, which may be related to the extremely high rate of glucose uptake by gas gland cells, leaving only low levels of glucose in the venous return to the rete.

Acknowledgements Open access funding provided by Austrian Science Fund (FWF). We would like to thank Marko Freese, JanDag Pohlmann, Reinhold Hanel, and the Thünen Institute of Fisheries Ecology, Hamburg, Germany, for providing yellow eels.

Funding information Financial support by the Austrian Fonds zur Förderung der wissenschaftlichen Forschung (FWF) is gratefully acknowledged (P26363-B25).

Open Access This article is distributed under the terms of the Creative Commons Attribution 4.0 International License (http:// creativecommons.org/licenses/by/4.0/), which permits unrestricted use, distribution, and reproduction in any medium, provided you give appropriate credit to the original author(s) and the source, provide a link to the Creative Commons license, and indicate if changes were made.

\section{References}

Aarestrup K, Okland F, Hansen MM, Righton D, Gargan P, Castonguay M, Bernatchez L, Howey P, Sparholt H, Pedersen MI, McKinley RS (2009) Oceanic spawning migration of the european eel (Anguilla anguilla). Science 325: 1660

Aouameur R, Da Cal S, Bissonnette P, Coady MJ, Lapointe JY (2007) SMIT2 mediates all myo-inositol uptake in apical membranes of rat small intestine. Am J Physiol Gastrointestinal and Liver Physiol 293:G1300-G1307

Capilla E, Diaz M, Albalat A, Navarro I, Pessin JE, Keller K, Planas JV (2004) Functional characterization of an insulin- responsive glucose transporter (GLUT4) from fish adipose tissue. Am J Physiol - Endocrinol Metab 287:E348-E357

Capilla E, Diaz M, Gutierrez J, Planas JV (2002) Physiological regulation of the expression of a GLUT4 homolog in fish skeletal muscle. Am J Physiol - Endocrinol Metab 283:E44 E49

Clow KA, Short CE, Hall JR, Gendron RL, Paradis H, Ralhan A, Driedzic WR (2016) High rates of glucose utilization in the gas gland of Atlantic cod (Gadus morhua) are supported by GLUT1 and HK1b. J Exp Biol 219:2763-2773

Coady MJ, Wallendorff B, Gagnon DG, Lapointe JY (2002) Identification of a novel Na+/myo-inositol cotransporter. J Biol Chem 277:35219-35224

Conde-Sieira M, Alvarez R, Lopez-Patino MA, Miguez JM, Flik G, Soengas JL (2013) ACTH-stimulated cortisol release from head kidney of rainbow trout is modulated by glucose concentration. J Exp Biol 216:554-567

Diaz M, Vraskou Y, Gutierrez J, Planas JV (2009) Expression of rainbow trout glucose transporters GLUT1 and GLUT4 during in vitro muscle cell differentiation and regulation by insulin and IGF-I. Am J Physiol Regul Integr Comp Physiol 296:R794-R800

Durif CMF, Dufour S, Elie P (2005) The silvering process of Anguilla anguilla: a new classification from the yellow resident to the silver migrating stage. J Fish Biol 66:1025-1043

Fukuzawa T, Fukazawa M, Ueda O, Shimada H, Kito A, Kakefuda M, Kawase Y, Wada NA, Goto C, Fukushima N, Jishage KI, Honda K, King GL, Kawabe Y (2013) SGLT5 reabsorbs fructose in the kidney but its deficiency paradoxically exacerbates hepatic steatosis induced by fructose. PLoS One 8:e56681

Grempler R, Augustin R, Froehner S, Hildebrandt T, Simon E, Mark M, Eickelmann P (2012) Functional characterisation of human SGLT-5 as a novel kidney-specific sodium-dependent sugar transporter. FEBS Letters 586:248-253

Hall JR, Clow KA, Short CE, Driedzic WR (2014) Transcript levels of class I GLUTs within individual tissues and the direct relationship between GLUT1 expression and glucose metabolism in Atlantic cod (Gadus morhua). J Comp Physiol B 184:483-496

Hall JR, MacCormack TJ, Barry CA, Driedzic WR (2004) Sequence and expression of a constitutive, facilitated glucose transporter (GLUT1) in Atlantic cod Gadus morhua. J Exp Biol 207:4697

Hall JR, Short CE, Driedzic WR (2006) Sequence of Atlantic cod (Gadus morhua) GLUT4, GLUT2 and GPDH: developmental stage expression, tissue expression and relationship to starvation-induced changes in blood glucose. J Exp Biol 209:4490-4502

Henkel CV, Burgerhout E, de Wijze DL, Dirks RP, Minegishi Y, Jansen HJ, Spaink HP, Dufour S, Weltzien FA, Tsukamoto K, van den Thillart GEEJ (2012) Primitive duplicate hox clusters in the european eel's genome. PLoS One 7:e32231

Horiba N, MasudaS TA, Takeuchi D, Okuda M, Inui KI (2003) Cloning and characterization of a novel Na+-dependent glucose transporter (NaGLT1) in rat kidney. J Biol Chem 278: 14669-14676

Kleckner RC (1980a) Swim bladder volume maintenance related to migratory depth in silver phase Anguilla rostrata. Science 208:1481-1482 
Kleckner RC (1980b) Swimbladder wall guanine enhancement related to migratory depth in silver phase Anguilla rostrata. Comp Biochem Physiol 65A:351-354

Kobayashi H, Pelster B, Scheid P (1990) $\mathrm{CO}_{2}$ back-diffusion in the rete aids $\mathrm{O}_{2}$ secretion in the swimbladder of the eel. Respir Physiol 79:231-242

Marin-Juez R, Capilla E, Carvalho-Simoes F, Camps M, Planas JV (2014) Structural and functional evolution of glucose transporter 4 (GLUT4): a look at GLUT4 in fish. In: Glucose homeostasis. AnonymousInTech, Rijeka, pp 37-67

Meyer A, Van de Peer Y (2017) From 2R to 3R: evidence for a fish-specific genome duplication (FSGD). BioEssays 27: 937-945

Moravec F (1992) Spreading of the nematode Anguillicola crassus (Dracunculoidea) among eel populations in Europe. Folia Parasitol 39:247-248

Mueckler M, Thorens B (2013) The SLC2 (GLUT) family of membrane transporters. Molec Aspects Med 34:121-138

Munakata K, Ookata K, Doi H, Baba O, Terashima T, Hirose S, Kato A (2012) Histological demonstration of glucose transporters, fructose-1,6-bisphosphatase, and glycogen in gas gland cells of the swimbladder: is a metabolic futile cycle operating? Biochem Biophys Res Com 417:564-569

Nawata CM, Dantzler WH, Pannabecker TL (2015) Alternative channels for urea in the inner medulla of the rat kidney. Am J Physiol - Renal Physiol 309:F916-F924

Nimeth K, Zwerger P, Würtz J, Salvenmoser W, Pelster B (2000) Infection of the glass-eel swimbladder with the nematode Anguillicola crassus. Parasitol 121:75-83

Nilsson S (2009) Nervous control of fish swimbladders. Acta Histochem. 111:176-184

Otero-Rodino C, Libran-Perez M, Velasco C, Lopez-Patino MA, Miguez JM, Soengas JL (2015) Evidence for the presence of glucosensor mechanisms not dependent on glucokinase in hypothalamus and hindbrain of rainbow trout (Oncorhynchus mykiss). PLoS One 10:e128603

Pankhurst NW (1982) Relation of visual changes to the onset of sexual maturation in the European eel Anguilla anguilla (L.) $\mathrm{J}$ Fish Biol 21:127-140

Panserat S, Plagnes-Juan E, Kaushik S (2001) Nutritional regulation and tissue specificity of gene expression for proteins involved in hepatic glucose metabolism in rainbow trout (Oncorhynchus mykiss). J Exp Biol 204:2351-2360

Pelster B (1995a) Mechanisms of acid release in isolated gas gland cells of the European eel Anguilla anguilla. Am J Physiol 269:R793-R799

Pelster B (1995b) Metabolism of the swimbladder tissue. Biochem Molec Biol Fishes 4:101-118

Pelster B (2001) The generation of hyperbaric oxygen tensions in fish. News Physiol Sci 16:287-291

Pelster B, Hicks J, Driedzic WR (1994) Contribution of the pentose phosphate shunt to the formation of $\mathrm{CO}_{2}$ in swimbladder tissue of the eel. J Exp Biol 197:119-128

Pelster B, Kobayashi H, Scheid P (1989) Metabolism of the perfused swimbladder of European eel: oxygen, carbon dioxide, glucose and lactate balance. J Exp Biol 144:495-506

Pelster B, Randall DJ (1998) The physiology of the Root effect. In: Perry SF, Tufts BL (eds) Fish Respiration. Academic Press, San Diego, pp 113-139
Pelster B, Scheid P (1993) Glucose metabolism of the swimbladder tissue of the European eel Anguilla anguilla. J Exp Biol 185:169-178

Pelster B, Weber RE (1991) The physiology of the Root effect. Adv Comp Environm Physiol 8:51-77

Pelster B, Schneebauer G, Dirks RP (2016) Anguillicola crassus infection significantly affects the silvering related modifications in steady state mRNA levels in gas gland tissue of the European eel. Front Physiol 7:175

Pérez LM, Fittipaldi M, Adrados B, Morato J, Codony F (2013) Error estimation in environmental DNA targets quantification due to PCR efficiencies differences between real samples and standards. Folia Microbiol 58:657-662

Polakof S, Panserat S, Soengas JL, Moon TW (2012) Glucose metabolism in fish: a review. J Comp Physiol B 182:10151045

Polakof S, Alvarez R, Soengas JL (2010) Gut glucose metabolism in rainbow trout: implications in glucose homeostasis and glucosensing capacity. Am J Physiol Regul Integr Comp Physiol 299:R19-R32

Polakof S, Soengas JL (2013) Evidence of sugar sensitive genes in the gut of a carnivorous fish species. Comp Biochem Physiol Part B: Biochem Mol Biol 166:58-64

Rasio EA (1973) Glucose metabolism in an isolated blood capillary preparation. Can J Biochem 51:701-708

Righton D, Aarestrup K, Jellyman D, Sebert P, Van den Thillart G, Tsukamoto K (2012) The Anguilla spp. migration problem: 40 million years of evolution and two millennia of speculation. J Fish Biol 81:365-386

Righton D, Westerberg H, Feunteun E, Okland F, Gargan P, Amilhat E, Metcalfe J, Lobon-Cervia J, Sjöberg N, Simon J, Acou A, Vedor M, Walker A, Trancart T, Brämick U, Aarestrup K (2016) Empirical observations of the spawning migration of European eels: the long and dangerous road to the Sargasso Sea. Science Advances 2:e1501694

Rytkönen KT, Akbarzadeh A, Miandare HK, Kamei H, Duan C, Leder EH, Williams TA, Nikinmaa M (2013) Subfunctionalization of cyprinid hypoxia-inducible factors for roles in development and oxygen sensing. Evolution 67 : 873-882

Schabetsberger R, Miller MJ, Dall'Olmo G, Kaiser R, Okland F, Watanabe S, Aarestrup K, Tsukamoto K (2016) Hydrographic features of anguillid spawning areas: potential signposts for migrating eels. Mar Ecol Prog Ser 554:141-155

Schabuss M, Kennedy CR, Konecny R, Grillitsch B, Reckendorfer W, Schiemer F, Herzig A (2005) Dynamics and predicted decline of Anguillicola crassus infection in European eels, Anguilla anguilla, in Neusiedler See, Austria. J Helminthol 79:159-167

Sebert P, Vettier A, Amerand A, Moisan C (2009) High pressure resistance and adaptation of European eels. In: Van den Thillart G, Dufour S, Rankin JC (eds) Spawning migration of the european eel. Springer Verlag, New York, pp 99-127

Smith FM, Croll RP (2011) Autonomic control of the swimbladder. Auton Neurosci 165:140-148

Sugiura SH, McDaniel NK, Ferraris RP (2003) In vivo fractional $\mathrm{Pi}$ absorption and NaPi-II mRNA expression in rainbow trout are upregulated by dietary P restriction. Am J Physiol Regul Integr Comp Physiol 285:R770-R781 
Taylor JS, Van de Peer Y, Braasch I, Meyer A (2001) Comparative genomics provides evidence for an ancient genome duplication event in fish. Philos Trans: Biol Sci 356:1661-1679

Tazawa S, Yamato T, Fujikura H, Hiratochi M, Itoh F, Tomae M, Takemura Y, Maruyama H, Sugiyama T, Wakamatsu A, Isogai T, Isaji M (2005) SLC5A9/SGLT4, a new $\mathrm{Na}^{+}$-dependent glucose transporter, is an essential transporter for mannose, 1,5-anhydro-D-glucitol, and fructose. Life Sciences 76: $1039-1050$

Terova G, Rimoldi S, Brambilla F, Gornati R, Bernardini G, Saroglia M (2009) In vivo regulation of GLUT2 mRNA in sea bass (Dicentrarchus labrax) in response to acute and chronic hypoxia. Comp Biochem Physiol Part B: Biochem Mol Biol 152:306-316

Walsh PJ, Milligan CL (1993) Roles of buffering capacity and pentose phosphate pathway activity in the gas gland of the gulf toadfish Opsanus beta. J Exp Biol 176:311-316
Wright EM, Turk E (2004) The sodium/glucose cotransport family SLC5. Pflügers Arch 447:510-518

Würtz J, Taraschewski H, Pelster B (1996) Changes in gas composition in the swimbladder of the European eel (Anguilla anguilla) infected with Anguillicola crassus (Nematoda). Parasitology 112:233-238

Würtz J, Taraschewski H (2000) Histopathological changes in the swimbladder wall of the European eel Anguilla anguilla due to infections with Anguillicola crassus. Disease Aquat Org 39:121-134

Yamada Y, Zhang H, Okamura A, Tanaka S, Horie N, Mikawa N, Utoh T, Oka HP (2001) Morphological and histological changes in the swim bladder during maturation of the Japanese eel. J Fish Biol 58:804-814 